\title{
20. PYRITIZED DIATOMS IN THE SEDIMENTS AT THE DISTAL END OF THE BENGAL FAN 1
}

\author{
Irena Kaczmarska² and James M. Ehrman ${ }^{3}$
}

\begin{abstract}
Well-preserved fossil pyritized diatom valves were retrieved from the upper Pliocene (CN 12d) sediments of the dista end of the Bengal Fan. Energy-dispersive X-ray microanalysis of these valves and those subjected to pyrite extraction with concentrated $\mathrm{HNO}_{3}$, documents the coexistence of original silica and pyrite within the fossil. Based on the preservation of untreated and treated valves, we postulate microcrystalline growth of pyrite within the matrix of the frustule.
\end{abstract}

\section{INTRODUCTION}

Pyrite is reported from many kinds of rocks from the Precambrian to Holocene and from numerous locations from all over the world (Love and Amstutz, 1966). Under favorable conditions it is formed in fresh, brackish, and marine sediments.

Biogeochemistry of sulfate reduction has advanced so that we can better understand the role of environmental parameters (deposition rate and the type of organic matter and inorganic iron, temperature, availability of alternative electron acceptors) in the rate of sulfate reduction and in the species of iron sulfides produced (Berner, 1969, 1985; Sweeney and Kaplan, 1973; Raiswell, 1982; Berner and Westrich, 1985; Morse and Cornwell, 1987). Less well understood are the processes that control the physicochemical relationship between organic or other matter and precipitating pyrite (Vallentyne, 1963; Berner, 1970; Rickard, 1970; Raiswell 1982).

Reports on diatoms and other fossils such as foraminifers, radiolarians, and sponges filled with aggregations of framboidal pyrite are common. Our review of relevant literature indicates that "pyritized diatoms" reported are, in fact, pyrite in-fillings of the frustule casts with occasionally preserved minute fragments demonstrating original ornamentation (Kato, 1967; Georgi 1976; Geroch, 1978; Thomas and Gradstein, 1981, Bignot, 1983). Generally the surface of the cast consists of a layer of framboids. Other frequently reported diatom remnants associated with pyrite are unaltered siliceous frustules filled with framboidal pyrite (Vallentyne, 1963; Schallreuter, 1984). In both cases, pyritization takes place in small chambers (created within buried skeletons or resulting from dissolution of the frustule) acting as a favorable microenvironment for crystallization of the pyrite.

Other reports relate to the pyritized organic globules that retained some of the original organic matter either within or around framboids (Love and Amstutz, 1966; Rickard, 1970). These observations form a basis for biogenic models of the origin of framboidal pyrite (Rickard, 1970). Later experiments and elemental analyses of such pyritized globules failed to detect appreciable concentrations of organic carbon in the dissolved framboid residues, thus casting doubt on the model (Vallentyne, 1963; Elverhoi, 1977).

\footnotetext{
${ }^{1}$ Cochran, J. R., and Stow, D. A. V., 1990. Proc. ODP, Sci. Results, 116: College Station, TX (Ocean Drilling Program).

2 Department of Biology, Mount Allison University, Sackville, N.B. E0A $3 \mathrm{C} 0$, Canada.

${ }^{3}$ Research and Development Division, Philip Morris U.S.A., Richmond, VA 23261, U.S.A.
}

To the best of our knowledge, diatom remnants have never been reported in a pyritized state where $\mathrm{FeS}_{2}$ and original diatomaceous silica co-occur. In this paper we report on the elemental composition and state of preservation of pyritized diatom valves and speculate on their possible origin.

\section{MATERIALS AND METHODS}

Pyritized diatom remains were fairly common in Pliocene sediments (Cores 116-117C-24 through -65). Only marine benthic and planktonic frustules were pyritized: e.g., Thalassiosira oestrupii (Ost.) Hasle var. venrickae Fryxell et Hasle, Coscinodiscus marginatus Ehr., C. radiatus Ehr., Actinocyclus spp., Thalassionema nitzschioides (Grun.) V.H., Thalassiothrix sp. cf. Th. longissima $\mathrm{Cl}$. et Grun., Biddulphia sp., and Triceratium favus Ehr. For scanning electron microscopy (SEM) and elemental analyses, large valves were hand picked from the sieved fraction $>64 \mu \mathrm{m}$. In all instances, the state of preservation was excellent. The frustules may have been fragmented, but the substructure of the valve revealed preservation of even the most minute details (Plate 1, Figs. 1-4; Plate 2, Figs. 2-3).

Under the dissecting microscope the frustules have a golden color. Under the light transmitting microscope all pyritized diatoms appeared black (Plate 2, Figs. 3-4).

Ten randomly selected specimens of various species were subjected to concentrated $\mathrm{HNO}_{3}$ treatment to remove the pyrite. The dissolution process was observed and time recorded. Elemental composition of six intact and three $\mathrm{HNO}_{3}$-treated diatom remnants was examined using an energy-dispersive X-ray system (EDS). Cleaned pyritized diatoms were transferred to carbon planchets. The samples were then sputter coated with approximately $20 \mathrm{~nm}$ of gold-palladium in a Hummer IV sputtering unit. SEM and energy-dispersive $\mathrm{X}$-ray microanalyses were performed on a JEOL JSM-35C equipped with a Kevex Unispec System 7000 EDS. Vertical scales of the spectra are indicated on Plate 2, Figs. 1A-1C; Fig. 7.

The thinnest silicified portion of the diatom valve occurs in the region of the areola occlusions. These areas were sufficiently electron transparent to allow selected area diffraction (SAD) to be performed. The technique reveals information regarding the crystallinity (or lack of) in the sample within the region selected. SAD was performed on 10 such areas of 4 valves using a JEOL $100 \mathrm{CX}$ transmission electron microscope (TEM).

\section{RESULTS AND DISCUSSION}

Elemental analysis of the individual valves revealed that $\mathrm{S}$ and $\mathrm{Fe}$ are major constituents of the pyritized diatoms. The peak ratio of Fe to $S$ is stable, approximately 1:2 (Plate 2, Figs. 1A-1C; Fig. 7). In addition to these two elements, all valves examined contained a variable amount of Si (Plate 2, Figs. 1A- 
1C; Fig. 7). Sporodic minute peaks of $\mathrm{Ca}, \mathrm{Al}$, and $\mathrm{K}$ were also detected. Their presence can be attributed to clay contamination. Sweeney and Kaplan (1973) report Ca and P in pyritic aggregates, some of which might represent pyrite infillings of the biotic casts (twigs, foraminifers). In pyrite grains from marine sediments Siesser (1978) found $\mathrm{K}, \mathrm{Si}, \mathrm{Al}, \mathrm{Ti}$, and $\mathrm{Mg}$ in quantities less than $0.05 \%$ by weight. Muza and Wise (1983) detected slightly higher quantities of these and $\mathrm{Ca}$ and $\mathrm{Zr}$ in sheet-like and framboidal pyrite.

Electron diffraction patterns of pyritized frustules show discrete spots and/or rings that indicate a microcrystalline organization of the matter. As diatom silica is consistently reported to be amorphous (Simpson and Volcani, 1981), we assume that this diffraction pattern represents a microcrystalline organization of the pyrite. Individual microcrystallites can be as small as $50 \mathrm{~nm}$ in diameter (Rickard, 1970) but are more commonly reported in the range of 200-300 nm (Criddle, 1974; Sweeney and Kaplan, 1973).

Individual microcrystallites were not resolvable in our SEM, on either the surface of the pyritized diatoms or on the broken edges. Lack of outgrowing crystals was observed earlier in framboidal pyrite, suggesting that it may be growing within an enclosure like an outer "skin" or within organic globules (Love and Amstutz 1966; Rickard, 1970; Sweeney and Kaplan, 1973).

Experimental removal of the pyrite from a clean, isolated pyritized diatom valve by dissolution in concentrated $\mathrm{HNO}_{3}$ is a fast process lasting no more than $5 \mathrm{~min}$. Upon drying, the residue becomes white and often collapses on itself. The residue retains its integrity nevertheless, conserving the size and shape of the diatom frustule after repeated rinsings in distilled water and embedding in a Hyrax resin. In all cases the structure of the original silica base layer and areolar ornamentation pattern were present (Plate 2, Fig. 8). The elemental spectra of the residue yielded counts for $\mathrm{Si}$ similar to those from pyritized valves. Minute quantities of $\mathrm{Fe}$ and some $\mathrm{P}$ were also detected (Plate 2, Fig. 7).

Love and Amstutz (1966) reported an organic, sponge-textured residue left after $\mathrm{FeS}_{2}$ was dissolved from the framboids. Carbon constituted $35 \%-71 \%$ of the residual matter. The majority $(75 \%)$ of organic matrix bodies from the framboids showed no distinct internal organization. Approximately $25 \%$ of the residues had puncture holes, presumably where pyrite crystals were. The organic matter, they concluded, did not control pyrite crystallization, but rather modified its own shape from within to that of crystals. Their evidence as to whether the organic matter was invested by pyrite and reformed or solidified around the pyrite was inconclusive.

Later efforts to investigate the residual organic matrix from dissolved framboids either failed or yielded such a minute amount of carbon that contamination could not be excluded (Vallentyne, 1963; Sweeney and Kaplan, 1973). Consequently, Sweeney and Kaplan (1973) and Elverhoi (1977) suggested that the matrix they detected must have been postcrystallic in origin. Therefore, the Love and Amstutz (1966) data are the only reports to date suggesting cohabitation of pyrite and biogenic matter.

In the case of pyritized diatoms from the Bengal Fan sediments, we speculate that the microenvironmental conditions are favorable for pyrite formation throughout the colloidal silica of the diatom frustule. At the same time, the fine structure of the silica matrix restricts the ultimate size of individual microcrystals. Pyrite microcrystallites must have invaded the frustules very gradually, permeating and/or replacing silica.

In contrast, conditions favorable for pyrite formation in fossil sponge spicules appear to exist only on their outer surfaces, and the fine structure of the spicule does not prevent free outgrowth of microcrystals (Plate 2, Figs. 5-6).
Evidence (see review in Simpson and Volcani, 1981) suggests that the silica in diatom valves is an aggregation of siliceous spheres. The primary building spherule diameter seems to be no smaller than 1-2 nm. The primary spherules aggregate into the secondary larger units, spheres commonly $30-50 \mathrm{~nm}$ in diameter but ranging between 10 and $200 \mathrm{~nm}$ in different species. These spheres seem to constitute building units of the tertiary, columnar aggregates. In Ditylum brightwellii (West) Grun., the width of columns (40-50 nm) corresponds to the diameter of the most common class of spheres. Such fine structure would provide suitable void spaces for pyrite microcrystalline growth.

We interpret the cryptocrystallic nature of the pyrite integrated into the diatom groundmass and lack of crystal outgrowth as an indicator of silica control of the space in which pyrite cryptocrystals were growing. Therefore, the diatomaceous silica demonstrates a different type of interaction between crystallizing pyrite and surrounding matter than that proposed for organic, sponge-textured matter by Love and Amstutz (1966).

\section{ACKNOWLEDGMENTS}

This study was supported by NSERC CSP grant 0020234, "Neogene paleoceanography at the ODP Leg 116 and 119, a North-south transect in the Indian Ocean." Philip Morris U.S.A. Research and Development kindly provided access to their electron microscopy facility.

\section{REFERENCES}

Berner, R. A., 1969. The synthesis of framboidal pyrite. Econ. Geol., 64:383-384.

1970. Sedimentary pyrite formation. Am. J. Sci., 268:1-23. 1985. Sulphate reduction, organic matter decomposition and pyrite formation. Phil. Trans. R. Soc. London, A315:25-38. and Westrich, J. T., 1985. Bioturbation and the early diagenesis of carbon and sulfur. Am. J. Sci., 285:193-206.

Bignot, G., 1983. Les lagunes sparnaciennes: une etape dans la conquete deseaux douces par les diatomees. Rev. Micropaleontol., 26: $15-21$.

Criddle, A. J., 1974. A preliminary description of microcrystalline pyrite from nannoplankton ooze at site 251 , southwest Indian Ocean. In Davies, T. A., Luyendyk, B. P., et al., Init. Repts. DSDP, 26: Washington (U.S. Govt. Printing Office), 603-611.

Elverhoi, A., 1977. Origin of framboidal pyrite in clayey Holocene sediments and in Jurassic black shale in the northwestern part of the Barents Sea. Sedimentology, 24:591-595.

Georgi, K. H., 1976. Mikrofaunistich-lithologische Untersuchungen der Hills-sandstein-Region Apt/Alb im Raum Salzgitter-Goslar. Mitt. Geol. Inst. Tech. Univ. Hannover, 13:5-112.

Geroch, S., 1978. Lower Cretaceous diatoms in the Polish Carpathians. Ann. Polish Geol. Soc., 48:283-295.

Kato, G., 1967. Biogenic pyrite from a Miocene formation of Shimane Peninsula, southwest Japan. Mem. Fac. Sci., Kyushu Univ., Ser. D, Geology, 18:313-330.

Love, L. G., and Amstutz, G. C., 1966. Review of microscopic pyrite. Fortschr. Miner., 43:273-309.

Morse, J. W., and Cornwell, J. C., 1987. Analysis and distribution of iron sulfide minerals in recent anoxic marine sediments. Mar. Chem., 22:55-69.

Muza, J. P., and Wise, S. W., Jr., 1983. An authigenic gypsum, pyrite, and glauconite association in a Miocene deep sea biogenic ooze from the Falkland Plateau, Southwest Atlantic Ocean. In Ludwig, W. J., Krasheninnikov, V. A., et al., Init. Repts. DSDP, 71: Washington (U.S. Govt. Printing Office), 361-367.

Raiswell, R., 1982. Pyrite texture, isotopic composition and the availability of iron. Am. J. Sci., 282:1244-1263.

Rickard, D. T., 1970. The origin of framboids. Lithos, 3:269-293.

Schallreuter, R., 1984. Framboidal pyrite in deep-sea sediments. In Hay, W. W., Sibuet, J.-C., et al., Init. Repts. DSDP, 75: Washington (U.S. Govt. Printing Office), 875-891.

Siesser, W. G., 1978. Petrography and geochemistry of pyrite and marcasite in Deep Sea Drilling Project Leg 40 sediments. In Bolli, Hans 
M., Ryan, W.B.F., Init. Repts. DSDP, Suppl. to Vols. 38, 39, 40, and 41: Washington (U.S. Govt. Printing Office), 767-775.

Simpson, T. L., and Volcani, B. E. (Ed.), 1981. Silicon and siliceous structures in biological systems: Berlin (Springer-Verlag).

Sweeney, R. E., Kaplan, I. R., 1973. Pyrite framboid formation: laboratory synthesis and marine sediments. Econ. Geol., 68:618-634.

Thomas, F. C., and Gradstein, F. M., 1981. Tertiary subsurface correlations using pyritized diatoms, offshore eastern Canada. Geol. Surv. Can., Curr. Res., Pt. B, Pap. 81-1B:17-23.
Vallentyne, J. R., 1963. Isolation of pyrite spherules from recent sediments. Limnol. and Oceanogr., 8:16-30.

Volcani, B. E., 1981. Cell wall formation in diatoms: Morphogenesis and biochemistry. In Simpson, T. L., and Volcani, B. E. (Ed.), Silicon and siliceous structures in biological systems: Berlin (SpringerVerlag).

Date of initial receipt: 1 March 1989

Date of acceptance: 2 October 1989

Ms 116B-129 

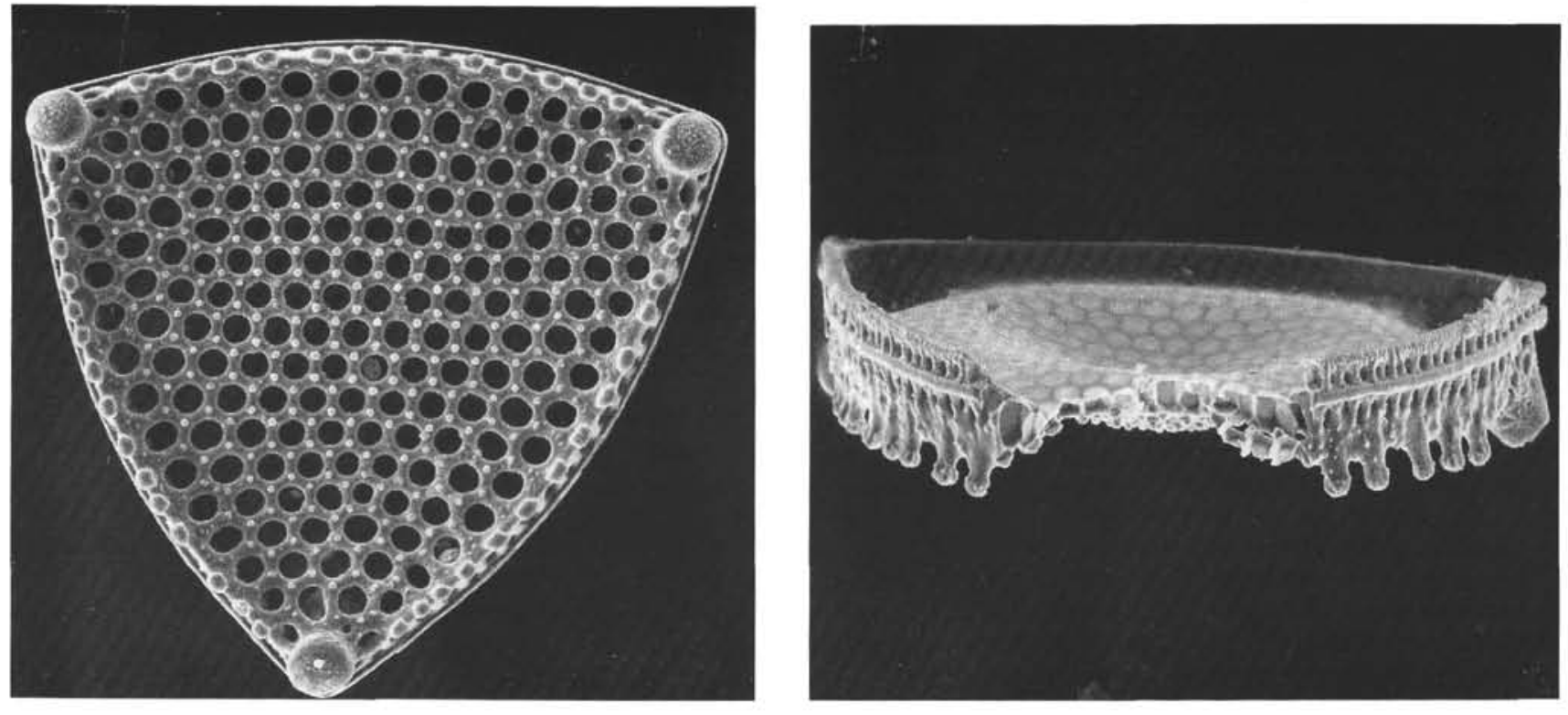

1

2
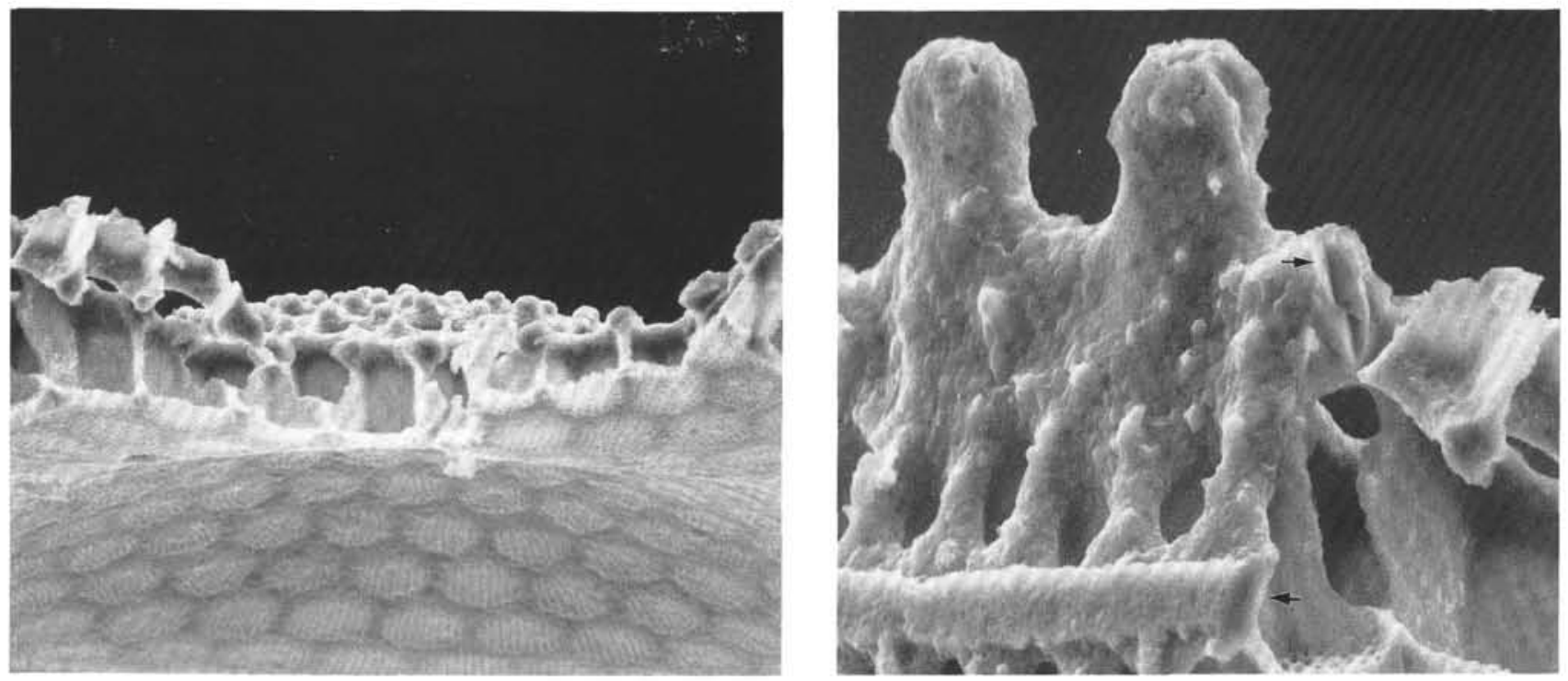

Plate 1. Pyritized specimens of Triceratium favus Ehr. Sample 116-717C-25X-5, 24-25 cm. On all SEM micrographs the bar represents $10 \mu \mathrm{m}$. 1. Details of the external surface of the valve face ornamentation. 2. Details of the valve mantle and internal valve face surface. 3. Cross-section of the areoles and the base layer of the valve. 4. Close-up of the mantle structure, even broken edges (arrows) of the valve do not resolve pyrite crystallites. 


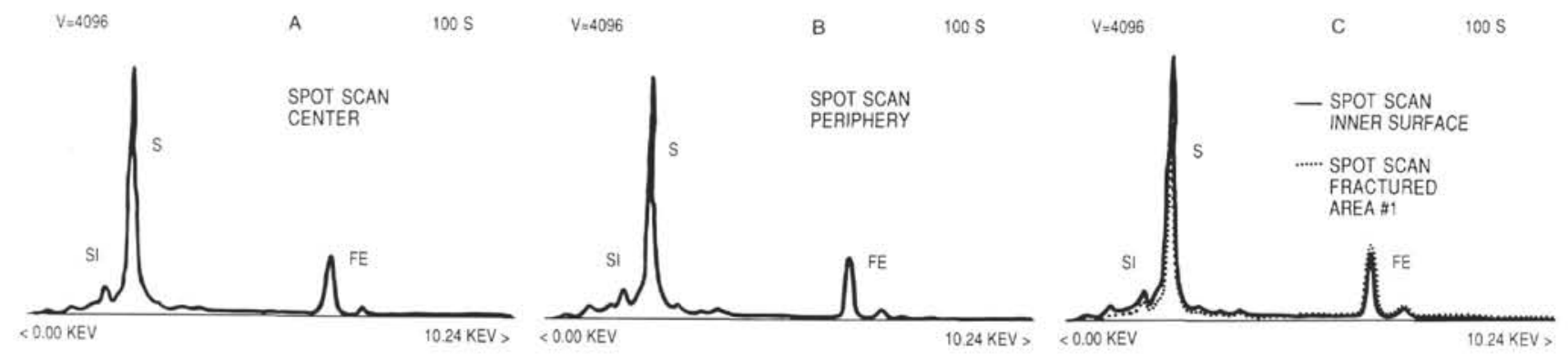

1

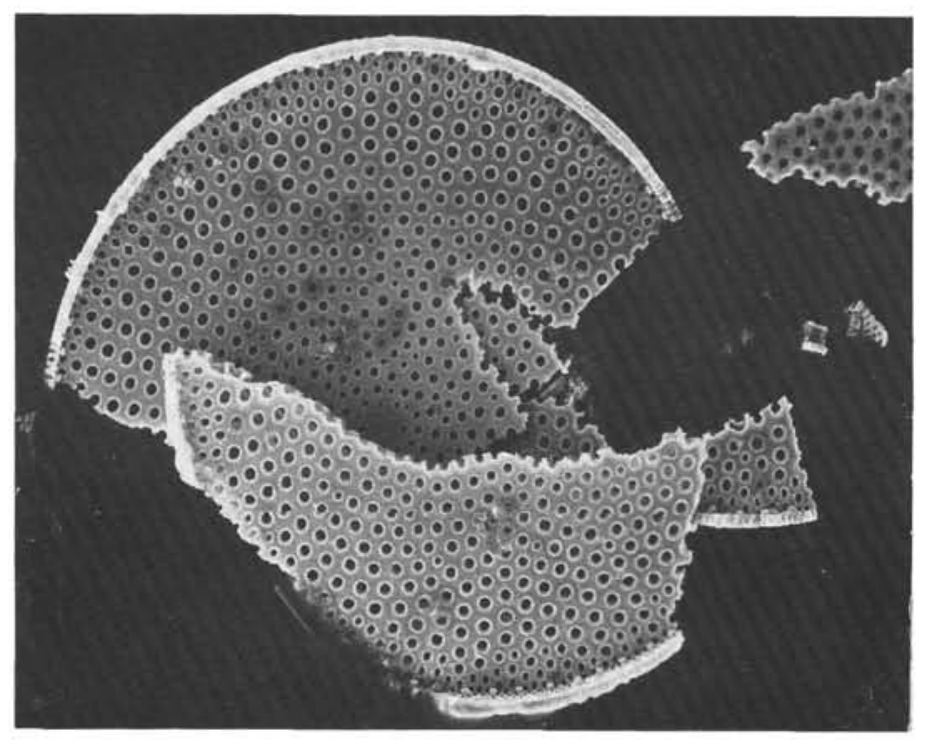

2

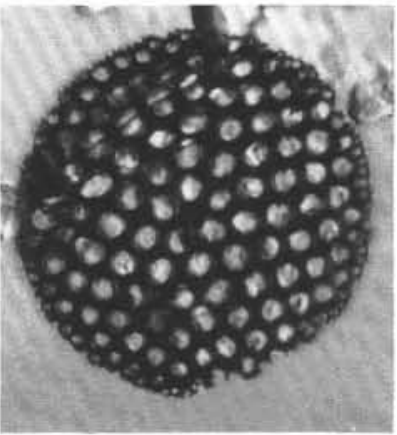

3

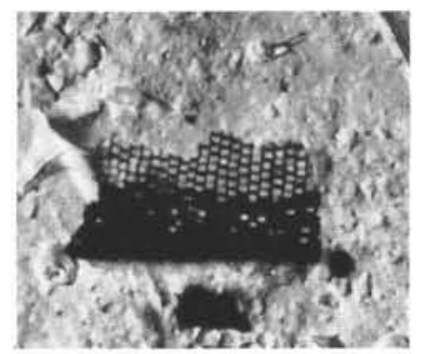

5

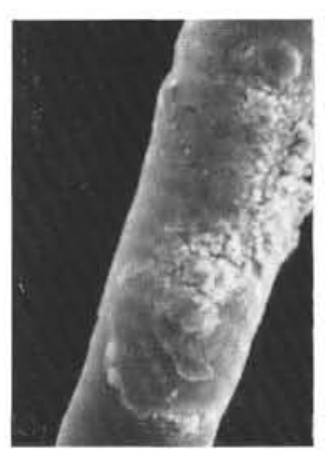

4

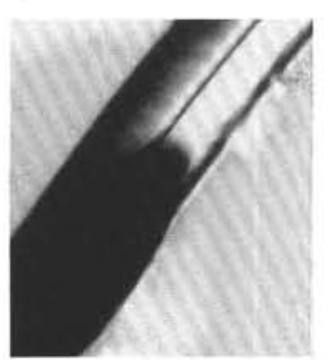

6

$100 \mathrm{~S}$

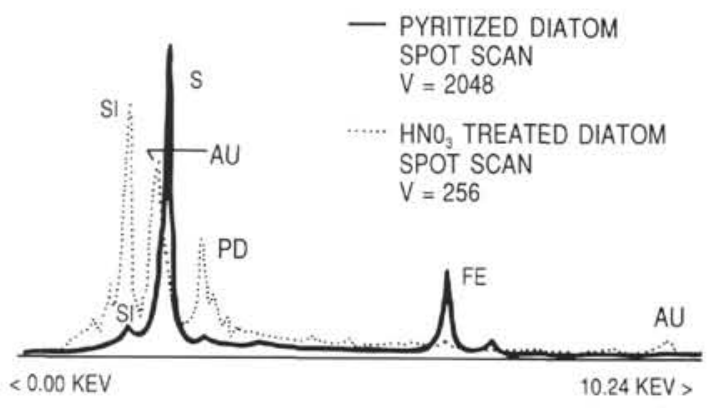

7

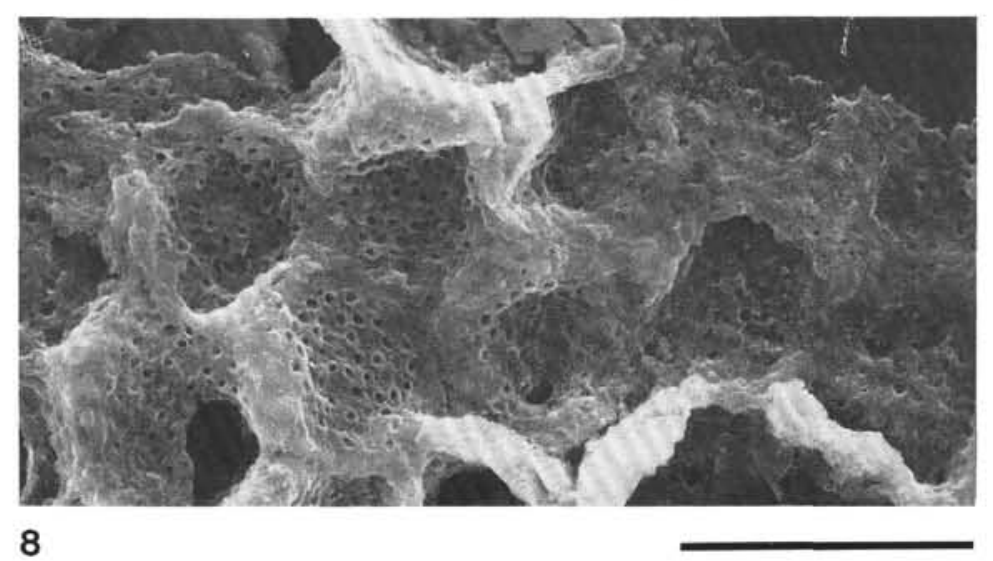

Plate 2. Elemental spectra and photomicrographs of the pyritized diatoms and sponge spicules. Sample 116-717C-25X-5, 24-25 cm. 1. A-C. EDS elemental composition of three pyritized diatom valves; Figures 1A and 1B represent spectra of the same valve examined at different areas; Figure 1C demonstrates spectra of two different valves. The vertical scales of the spectra are indicated by V. 2. SEM micrograph of the internal surface of a pyritized Coscinodiscus radiatus Ehr. 3. Pyritized Thalassiosira oestrupii (Ost.) Hasle var. venrickae Fryxell et Hasle (LTM, 1900×). 4. Pyritized fragment of Ethmodiscus sp. (LTM, 700 ×). 5. SEM micrograph of partially pyritized sponge spicule. 6. Partially pyritized sponge spicule (LTM, $1900 \times$ ). 7. Overlayed elemental spectra of a pyritized valve (solid line) and fragment of pyrite extracted valve (dashed line). Note two different vertical scales (V) for the spectra. 8. SEM micrograph of the pyrite extracted valve of Triceratium favus Ehr.; notice the base silica layer ornamentation and remnants of areoles. 